BBA 55900

\title{
SOME STUDIES ON THE METABOLISM OF PHOSPHOLIPIDS IN PLASMA MEMBRANES FROM RAT LIVER
}

E. J. VICTORIA*, L. M. G. VAN GOLDE, K, Y. HOSTETLER, G. L. SCHERHHOF AND L. L. M. VAN DEENEN

Biochemisch Laboratorium, State University of Utrecht, Vondellaan 26, Utrecht (The Netherlands) (Received March gth, 1971)

SUMMARY

I. Rat liver plasma membranes were isolated by rate-isopycnic zonal centrifugation. A method is described for the size I4 zonal rotor. The isolated membranes had an isopycnic banding density of $4 \mathrm{r} .2 \%$ sucrose $(\mathrm{w} / \mathrm{w})$. On the basis of studies with eleven marker enzymes and electron microscopy, at least $90 \%$ of the fraction consisted of plasma membranes. The electron micrographs showed a predominantly vesicular appearance with few junctional complexes.

2. Plasma membranes exhibited virtually no CDP-choline:I,2-diacyl-snglycerol cholinephosphotransferase activity and thus appear incapable of significant in vitro synthesis of phosphatidylcholine by the cytidine nucleotide pathway.

3. Phosphatidylglycerol was the major product of sn-glycerol-3-phosphate esterification by plasma membranes in the presence of CDP-diglyceride at $\mathrm{pH} 7.5$. The product was identified by thin-layer chromatography using pure phosphatidylglycerol as a reference compound, and by paper chromatography of the products obtained by hydrolysis with phospholipase $D$.

4. Incubation of plasma membranes with labeled exogenous phospholipids in the presence of $\mathrm{Ca}^{2+}$ resulted in the formation of fatty acids and monoacylphosphoglycerides. Analyses of the reaction products indicated that the phospholipase $A$ mainly attacks the 2-position of the phosphoglyceride molecule. Plasma membrane phospholipase $A$ also acted on labeled endogenous phosphatidylethanolamine in the presence of $\mathrm{Ca}^{2+}$.

5. A partial characterization of the phospholipase indicated that it required $\mathrm{Ca}^{2+}$ for optimal activity, was insensitive to $N$-ethylmaleimide and deoxycholate, and was relatively heat stable. Its $\mathrm{pH}$ optimum was 8.o. The following was the preferred order of hydrolysis: phosphatidylethanolamine $>$ phosphatidylglycerol $>>>$ phosphatidylcholine.

6. Lysophospholipase was not detected in rat liver plasma membranes under

Abbreviation: EGTA, ethyleneglycol-bis-( $\beta$-aminoethylether $)-N, N^{\prime}$-tetraacetic acid.

* Present address: Laboratory of Biochemistry, National Heart and Lung Institute, National Institutes of Health, Bethesda, Md. 200r4 (U.S.A.). 
conditions in which maximal activity of this enzyme was observed in rat liver 100000 $\times g$ supernatant.

\section{INTRODUCTION}

In the past few years considerable interest has been focused on the study of isolated plasma membranes from solid tissues. ${ }^{1}$. Most of these studies have involved membranes obtained from liver. Although most workers have used the flotation technique introduced by NEVILLE ${ }^{2}$, rate-isopycnic zonal centrifugation has recently been applied to the isolation of plasma membranes ${ }^{3}$.

The lipid composition of liver plasma membranes is extensively documented in the literature ${ }^{4-10}$. Few studies, however, have been concerned with metabolic rather than analytic aspects of plasma membrane lipids. In I 968 it was demonstrated that plasma membranes could incorporate long-chain acyl-CoA esters, primarily into phospholipids ${ }^{7}$. It was also reported that the plasma membranes could acylate exogenous lysolecithins ${ }^{11}$. Acyltransferases catalyzing the conversion of monoacyl phosphoglycerides into the diacyl compounds have been reported in microsomes ${ }^{12}$ and mitochondria ${ }^{13-15}$. Because such an acylation mechanism, combined with (a) phospholipase(s) could represent a mechanism involved in the renewal of membrane phospholipids ${ }^{16-18}$, it was thought of interest to investigate whether the plasma membranes possess phospholipase A activity and, if present, to assess the positional specificity of this enzyme.

A phospholipase acting preferentially on the 2-position has been demonstrated in rat liver mitochondria ${ }^{18,20}$ whereas microsomes were shown to possess a phospholipase A attacking preferentially the $\mathrm{I}$-position of phosphoglycerides ${ }^{21,22}$. Lyso somes of rat liver were found to contain both phospholipase $A_{1}$ and $A_{2}$ activities ${ }^{23}$. While this manuscript was in preparation, ToRqueBIAu et al. ${ }^{24}$ described the presence of phospholipase $\mathrm{A}$ activity towards exogenous substrates in plasma membranes. In the present study, it was also investigated whether the enzyme acted on endogenous substrate as well, and the positional specificity of the enzyme was determined. No significant de novo synthesis of the major phospholipids in plasma membranes has been reported. Although most of the enzymes involved in de novo synthesis of phospholipids are located in the endoplasmic reticulum ${ }^{25}$, phosphatidylglycerol biosynthesis has been reported to occur predominantly in the mitochondrion ${ }^{26}$. Phosphatidylglycerol was recently reported to be present also in plasma membranes ${ }^{8}$. In the present study, the possible role of the plasma membrane in the biosynthesis of phosphatidylglycerol was investigated.

\section{MATERIALS AND METHODS}

\section{Isolation of plasma membranes by rate-isopyonic zonal centrifugation}

Plasma membranes were isolated from the livers of $250-300-\mathrm{g}$ fed male Wistar rats. The basic procedure is that of ANDERSON et al. ${ }^{3}$, but it was modified for the use with a Beckman Til4 rotor. For each run, I5 g of liver were homogenized with 25 strokes of a loose-fitting Dounce homogenizer in about roo $\mathrm{ml}$ of $\mathrm{x} \mathrm{mM} \mathrm{NaHCO}_{3}$, $\mathrm{pH} 7.6$. The homogenate was filtered through eight layers of cheese cloth and the 
filtrate diluted with the bicarbonate solution to $750 \mathrm{ml}$. This suspension was centrifuged at $25800 \mathrm{~g}^{\prime} \mathrm{min}$ in the GSA rotor of a $\mathrm{RC} 2-\mathrm{B}$ Sorvall centrifuge. After removal of the supernatant, the loose pellets were combined by suspension in a total volume of $50 \mathrm{ml}$ of bicarbonate solution with five strokes of the Dounce homogenizer. This material was used for zonal centrifugation.

With a Beckman I4I High Capacity gradient pump, a 450-ml density gradient ranging from $\mathrm{I} 9$ to $35 \%$ sucrose $(\mathrm{w} / \mathrm{w})$ was delivered into a TiI 4 zonal rotor rotating at $3000 \mathrm{rev} . \mathrm{min}$ in a Beckman $\mathrm{L}-265 \mathrm{~K}$ centrifuge. Overlay and cushion solutions used were $\mathrm{I} \mathrm{mM} \mathrm{NaHCO}_{3}$ and $45 \%$ sucrose $(\mathrm{w} / \mathrm{w})$, respectively. Following the injection of $50 \mathrm{ml}$ of sample material and $50 \mathrm{ml}$ of overlay into the rotor core, the rotor was accelerated to $5000 \mathrm{rev} / \mathrm{min}$. After Io $\mathrm{min}$, the rotor was decelerated to $3000 \mathrm{rev} . \mathrm{min}$ and ten $40-\mathrm{ml}$ fractions were displaced from the rotor core with cushion solution. The outflow transmittance was continuously monitored at $254 \mathrm{~nm}$ with an I.KR IJvicord II recorder. After injection of $\mathrm{I} 5 \mathrm{ml}$ of overlay, the rotor was accelerated to 20000 $\mathrm{rev} / \mathrm{min}$ for $\mathrm{I}_{5} \mathrm{~min}$. Upon deceleration to $3000 \mathrm{rev} / \mathrm{min}$, the rotor was again unloaded. Refractive indices were measured at $20^{\circ}$ in a Bausch and Lomb Abbe-3L refractometer. The plasma membrane-containing fractions were pooled and diluted I:I $(\mathrm{v} / \mathrm{v})$ with bicarbonate solution and sedimented at $105000 \times \mathrm{g}$ for $60 \mathrm{~min}$ in the Beckman No. 30 rotor. The pellets were stored at $-20^{\circ}$. The yield was approx. $0.5 \mathrm{mg}$ protein per $g$ wet liver.

\section{Other subcellular fractions}

Mitochondrial and microsomal fractions were isolated in $0.25 \mathrm{M}$ sucrose by classical differential centrifugation.

\section{Marker enzymes}

The following enzymes were used as markers and assayed as described in the references: succinate:cytochrome $c$ reductase ${ }^{27}$ (EC I.3.99.I); monoamine oxidase ${ }^{28}$ (EC I.4.3.4, substrate kynuramine); rotenone-insensitive NADH:cytochrome $c$ reductase $^{29}$ (EC 1.6.2.I); rotenone-insensitive $\mathrm{NADPH}$ : cytochrome $c$ reductase $^{29}$ (EC I.6.2.3); acid deoxyribonuclease ${ }^{30}$ (EC 2.I.4.6); CDP-choline: 1,2 diacyl-sn-glycerol cholinephosphotransferase ${ }^{1.5}$ (EC 2.7.8.2); acid phosphatase ${ }^{31}$ (EC 3.x.3.2, substrate $\beta$-glycerophosphate); $5^{\prime}$-nucleotidase ${ }^{32}$ (EC 3.I.3.5, substrate $5^{\prime}$-AMP); ATPase ${ }^{32}$ (EC 3.6.I.3); $\left(\mathrm{Na}^{+}, \mathrm{K}^{+}\right) \mathrm{Mg}^{2+}-\mathrm{ATPase}^{32}$ (EC 3.6.I.4) and glucose-6-phosphatase ${ }^{33}$ (EC 3.I.3.9). All spectrophotometric measurements were carried out in a Unicam SP 5 oo recording spectrophotometer except for monoamine oxidase which was assayed in a Hitachi-Perkin Elmer 356 double-wavelength spectrophotometer at $360-332 \mathrm{~nm}$. Protein was measured by the method of LowRY et al. ${ }^{34}$ and phosphorus according to that of CHEN et al. ${ }^{35}$.

\section{Electron microscopy}

Before being processed for electron microscopy, membranes were dialysed against $0.9 \% \mathrm{NaCl}$. Aliquots of these dialysed suspensions, containing approx. $0.5 \mathrm{mg}$ of protein, were centrifuged for $5 \mathrm{~min}$ at maximal speed in a Beckman Microfuge. After discarding the supernatants, the pellets were covered with $0.5 \mathrm{ml}$ of a $\% \mathrm{OsO}_{4}$ solution buffered with veronal-acetate, $\mathrm{pH} 7.4$ and containing $\mathrm{CaCl}_{2}$ (ref. 36). Fixation was continued for $\mathrm{I}$ h at $4^{\circ}$. The fixed samples were dehydrated in a graded series of 
acetone-water mixtures. The pellets were cut to size and embedded in Araldite 5I2.

White to gray sections were cut on a Reichert $\mathrm{OmU}_{2}$ ultramicrotome with a Dupont de Nemours diamond knife. The sections were picked up on copper grids which were covered with a parlodion film coated with a thin layer of carbon. The sections were stained for $5 \mathrm{~min}$ by floating on a drop of saturated uranylacetate followed by staining with lead citrate. The specimens were examined in a Siemens Elmiskop I electron microscope at an accelerating voltage of $60 \mathrm{kV}$. Micrographs were taken at instrumental magnifications of approx. 4000 and 56000 on Agfa Scientia 23D50 plates. Accurate magnifications were determined according to the method described by Elbers AND PIETERs ${ }^{37}$.

\section{Labeled substrates}

2- $\left[{ }^{3} \mathrm{H}\right]-5 n$-Glycero-3-phosphate was prepared from $2-\left[{ }^{3} \mathrm{H}\right]$ glycerol and ATP in the presence of glycerokinase and purified according to the method of BUBLITZ AND $\mathrm{KENNEDY}{ }^{38}$. The specific activity was $0.5 \mathrm{mC} / \mu$ mole.

I-Palmitoyl-2-[I- $\left.{ }^{14} \mathrm{C}\right]$ oleoyl-3-sn-phosphatidyl-I'-sn-glycerol was isolated from Mycoplasma laidlawii strain B grown in lipid-poor medium containing $75 \mu \mathrm{C}$ of $\left[\mathrm{r}^{14} \mathrm{C}\right]$ oleic acid per 1 as described by McEllhaney and Tourtelottr ${ }^{39}$. Analyses of the products after degradation with Crotalus adamanteus venom indicated that $80 \%$ of the label was present at the 2 -position. The specific activity was $1.8 \cdot 10^{6}$ counts $/ \mathrm{min}$ per $\mu$ nnole.

I- $\left[9, \mathrm{IO}^{3} \mathrm{H}\right]$ Stearoyl-2-oleoyl-3-sn-phosphatidyl-I'-sn-glycerol was similarly isolated from Mycoplasma grown in a medium containing $400 \mu \mathrm{C}$ of $\left[9,10^{-3} \mathrm{H}\right]$ stearic acid per 1 . Labeled stearate was $74 \%$ at the I-position. The specific activity was I.5. IO ${ }^{6}$ counts/min per $\mu$ mole.

I-Saturated $2-\left[\mathrm{I}^{14} \mathrm{C}\right]$ linoleoyl-3-sn-phosphatidylethanolamine was prepared as previously described ${ }^{21}$. Linoleic acid was $97 \%$ at the 2 -position. The specific activity was $7 \cdot 10^{6}$ counts $/ \mathrm{min}$ per $\mu$ mole.

I-[I-14C]Palmituyl-sn-glycero-3-phosphorylchuline, specific activity 362 counts/ min per nmole, was a generous gift of Dr. H. Van den Bosch of this laboratory.

\section{Assay for phosphatidylglycerol biosynthesis by isolated plasma membranes}

Plasma membranes were incubated in a medium essentially the same as that of KIYAsv et al. ${ }^{26}$ (see legend to Fig. 3). The radioactive lipid product was determined by a filter paper disc assay as described by GoLDFINE ${ }^{40}$. The filter paper discs were counted in vessels containing $16 \mathrm{ml}$ of scintillation fluid $(0.5 \%$ PPO and $0.03 \%$ POPOP in toluene). Quench corrections were made by the channels ratio method.

Identification of the radioactive product was as follows. After incubation as described for Fig. 3 , the total lipids were extracted according to BLIGH AND DYER ${ }^{41}$ : concentrated to a small volume in vacuo and applied to $0.5 \mathrm{~mm}$ thick thin-layer plates. Chromatography was carried out in two solvent systems. One consisted of chloroformmethanol-water-25\% ammonia $(70: 30: 3: 2$, by vol.) and was used with plates prepared from silica gel $\mathrm{H}$ in $0.4 \mathrm{M}$ sodium borate. The other was chloroform-methanolacetic acid-water (50:25:7:3, by vol.) and was used with silica gel $\mathrm{H}$ plates slurried with I $\mathrm{mM} \mathrm{Na}_{2} \mathrm{CO}_{3}$. Reference standards of phosphatidylglycerol were obtained from Mycoplasma laidlawii by the method of Shaw et al. ${ }^{2}$. Spots were identified by exposure to iodine vapors or by development with periodate-Schiff reagent. 
The thin-layer plates were scanned for radioactivity with a Panax TLC scanner (Panax Equipment Ltd., Great Britain) and the single radioactive lipid found was eluted from the silica gel by the method of SKIPSKI et al. ${ }^{43}$. The eluted lipid was hydrolyzed with phospholipase D prepared from cabbage as described by LonG ${ }^{44}$. After partitioning as described by BLIGH AND DYER ${ }^{41}$, the water-soluble products were applied to Whatman No. I filter paper. Descending chromatography was carried out in $n$-propanol-25\% ammonia-water (6:3:I, by vol.). Glycerol-3-phosphate and glycerol were used as reference standards. After developing the guide spots with periodateSchiff reagent, the paper was scanned for radioactivity.

Assay of plasma membrane phospholipase $A$ activity towards exogenous labeled phospholipids

Labeled phospholipids, after evaporation to dryness under a stream of nitrogen, were resuspended in water at a concentration of $\mathrm{I} \mu \mathrm{mole} / \mathrm{ml}$ and sonicated for $\mathrm{I}$ min with a Branson sonifier at a setting of $4 \mathrm{~A}$. Appropriate aliquots of the phospholipid dispersions were added to the standard incubation mixture which contained the following or multiples thereof: Io $\mathrm{mM}$ Tris- $\mathrm{HCl},(\mathrm{pH} 8.0)$, Io $\mathrm{mM} \mathrm{Ca}^{2+}$ and $0.050 \mathrm{mg}$ plasma membrane protein in a total volume of $0.25 \mathrm{ml}$. The incubations were carried out in a shaking water bath at $37^{\circ}$ and the reactions were stopped by the addition of I $\mathrm{ml}$ of methanol-chloroform $(2: \mathrm{I}, \mathrm{v} / \mathrm{v})$. Lipid extraction was carried out by the method of BriGH AND DYER ${ }^{41}$, after acidification to $\mathrm{pH} 4.5$ with $0.5 \mathrm{M} \mathrm{H}_{2} \mathrm{SO}_{4}$.

The lipid extract was chromatographed on silica gel $\mathrm{G}$ thin-layer plates in two solvent systems: first in chloroform-light petroleum-acetic acid $(65: 33: 2$, by vol.) and subsequently in chloroform-methanol-water $(65: 35: 4$, by vol.) in the same direction. Unlabeled compounds were co-chromatographed in order to facilitate identification. Following visualization by iodine vapor, the appropriate spots were scraped off into vials containing $15 \mathrm{ml}$ of scintillation fluid. For ${ }^{14} \mathrm{C}$-labeled compounds, the scintillation medium consisted of $0.7 \%$ PPO, $0.03 \%$ dimethyl-POPOP and $10 \%$ naphthalene per 1 of dioxane diluted 5 parts to I of water $(\mathrm{v} / \mathrm{v})$. For tritiated samples the scintillation medium consisted of $0.5 \%$ PPO and $0.03 \%$ dimethyl-POPOP per 1 of toluene diluted with Triton $\mathrm{X}$-I 100 and water in a ratio of $2: \mathrm{I}: 0.2$ (by vol.). A Packard TriCarb liquid scintillation counter was employed for the measurements.

Assay of plasma membrane phospholipase $A$ activity towards endogenous labeled phospholipid

Two rats were injected intraperitoneally with $25 \mu \mathrm{C}$ of $\left[\mathrm{I}, 2^{-14} \mathrm{C}\right]$ ethanolamineHCl. After $3 \mathrm{~h}$ the animals were sacrificed and the plasma membranes isolated. $\mathrm{I} .35 \mathrm{mg}$ plasma membrane proteins were incubated at $37^{\circ}$ in a medium containing $0.5 \mathrm{mM}$ EGTA, $2 \mathrm{mM} \mathrm{Ca}{ }^{2+}, 66 \mathrm{mM} \mathrm{KCl}, 53 \mathrm{mM}$ Tris- $\mathrm{HCl}$ buffer, $\mathrm{pH} 7,4$, in a total volume of $0.5 \mathrm{ml}$. The reaction was started by addition of $\mathrm{Ca}^{2+}$. At the indicated times, the reaction was stopped by addition of excess EGTA (final concentration, $5 \mathrm{mM}$ ) followed by $2 \mathrm{ml}$ of chloroform-methanol $(\mathrm{I}: 2, \mathrm{v} / \mathrm{v})$. The lipids were extracted as described by BLIGH AND DYER" and then chromatographed on silica gel $G$ thin-layer plates and lysophosphatidylethanolamine spots were identified by means of reference standards and scraped directly into scintillation vials. 
Lysophospholipase assay

The assay for lysophospholipase was carried out as described in detail by VAN DEN Bosch et al. ${ }^{45}$.

\section{Chemicals}

2- $\left.{ }^{3} \mathrm{H}\right]$ glycerol and labeled fatty acids were purchased from the Radiochemical Centre, Amersham (G.B.). [I.2-14C $]$ Ethanolamine- $\mathrm{HCl}$ was obtained from New England Nuclear (U.S.A.). CDP-choline and CDP-diglyceride were obtained from Tracerlab (U.S.A.) and Koch-Light (G.B.), respectively. ATP, kynuramine-di-HBr and glucose6-phosphate were bought from Sigma (U.S.A.), AMP from Merck (Germany), cytochrome $c$ and sn-glycero-2-phosphate from Fluka (Switzerland), NADH, NADPH, coenzyme A, and glycerokinase (EC 2.I.I.3) from Boehringer (Germany), rotenone from Aldrich (U.S.A.), and DNA from Koch-Light (G.B.).

\section{RESULTS}

\section{Sedimentation properties of plasma membranes}

A typical sedimentation profile of plasma membranes is shown in Fig. I. The average banding density for five runs was $4 \mathrm{I} .2 \%$ sucrose $(\mathrm{w} / \mathrm{W})(d=\mathrm{I} . \mathrm{I} 82 \mathrm{~g} / \mathrm{ml})$.

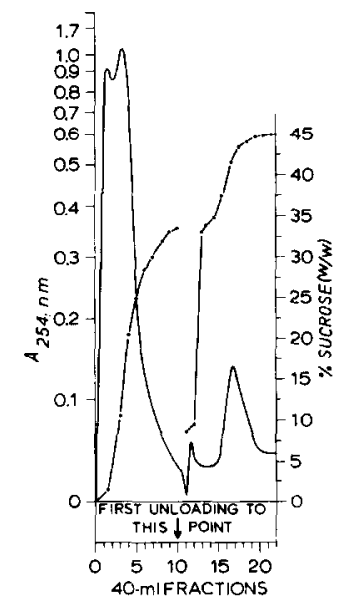

Fig. I. Rate-isopycnic zonal separation of plasma membranes in the TiI 4 rotor. Fractions I6, I7, and 8 represent mainly plasma membranes.

\section{Distribution of marker enzymes in cell fractions}

Table I shows the specific activities of enzymes present in the different cell fractions studied. The activities of mitochondrial, microsomal, and lysosomal enzymes are drastically reduced in the plasma membranes. Conversely, there is an enrichment in those enzymes bclicved to be associatcd with the plasma membranc ${ }^{32}$ (5'-nucleotidase and $\left.\left(\mathrm{Na}^{+}, \mathrm{K}^{+}\right) \mathrm{Mg}^{2+} \mathrm{ATPase}\right)$. On the basis of studies with rotenone-insensitive NADPH:cytochrome $c$ reductase, glucose-6-phosphatase, succinate:cytochrome $c$ reductase, monoamine oxidase and acid phosphatase, the maximal possible contamination with microsomes, intact mitochondria, mitochondrial outer membrane fragments 


\section{TABLE I}

SPECIFIC ACTIVITIES OF MARKER ENZYMES IN SUBCELLULAR FRACTIONS OF RAT LIVER

The results are given as nmoles substrate or product transformed per min per mg protein, except for monoamine oxidase which is expressed in arbitrary absorbance units/min per $\mathrm{mg}$ protein. All values are the means of triplicate determinations. In all cases the dispersion was less than $5 \%$. For plasma membranes, the assays were carricd out in pooled samples from at least five zonal runs. -., Not determined.

\begin{tabular}{|c|c|c|c|c|}
\hline Marker enzyme & $\begin{array}{l}\text { Plasma } \\
\text { membranes }\end{array}$ & $\begin{array}{l}\text { Total } \\
\text { homogenate }\end{array}$ & $\begin{array}{l}\text { Mitochondria } \\
\text { (contanimg } \\
\text { lysosomes) }\end{array}$ & Microsomes \\
\hline Succinate:cytochrome $c$ reductase & 0.5 & 22.4 & 60.8 & - \\
\hline $\begin{array}{l}\text { Monoamine oxidase } \\
\text { (Rotenone-insensitive) NADH :cyto- }\end{array}$ & 0.002 & 0.003 & 0.024 & -. \\
\hline $\begin{array}{l}\text { chrome } c \text { reductase } \\
\text { (Rotenone-insensitive) NADPH:cyto- }\end{array}$ & 31.3 & $x 51.0$ & 74.6 & 700.0 \\
\hline chrome $c$ reductase & 5.0 & 9.2 & - & $64 \cdot 7$ \\
\hline Acid deoxyribonuclease & 0.6 & 3.4 & 24.4 & - \\
\hline $5^{\prime}$-Nucleotidase & 594.0 & 63.0 & - & 91.0 \\
\hline Acid phosphatase & 3.0 & 12.9 & 79.0 & - \\
\hline $\mathrm{Mg}^{2+}$ ATPase & $x 760.0$ & 246.0 & - & 一 \\
\hline$\left(\mathrm{Na}^{+}, \mathrm{K}^{+}\right) \mathrm{Mg}^{2+}+$ ATPase & 320.0 & 27.0 & - & - \\
\hline Glucose-6-phosphatase & 35.0 & - & - & 350.0 \\
\hline Cholinephosphotransferase & 0.044 & - & - & 0.720 \\
\hline
\end{tabular}

and lysosomes was judged to be less than $10 \%, \mathrm{I} \%, \mathrm{I} \%$ and $\mathrm{I} \%$, respectively. For the calculation of lysosomal contamination, a purposely high figure of $20 \%$ was assumed for the amount of lysosomes present in the classical mitochondrial pellet ${ }^{46}$. The outer membranc calculation is based on a mitochondrial content of $10 \%$ outer membrane on a protein basis ${ }^{4-49}$.

The amount of cholinephosphotransferase in plasma membranes relative to that in microsomes does not exceed the corresponding value for glucose-6-phosphatase and rotenone-insensitive-NADPH:cytochrome $c$ reductase, indicating that the de novo synthesis of lecithin is localized almost exclusively in the endoplasmic reticulum ${ }^{15,25}$.

\section{Electron microscopy of isolated plasma membranes}

Electron micrographs of the membrane preparations showed that they were essentially free from whole mitochondria, lysosomes and nuclei. Microsomal and mitochondrial outer membrane contamination is somewhat harder to assess morphologically, since in thin sections vesicles derived from outer membrane fragments and smooth microsomes cannot be discriminated from small plasma membrane vesicles. The presence, however, of microsomes derived from rough endoplasmic reticulum can, almost certainly, be excluded. Although rough-surfaced membranes were occasionally observed, it was clear from their irregular size and shape at high magnification that the particles responsible for this rough appearance were not ribosomal in origin but rather were due to nonspecific stain deposits.

Most of the membrane material was present as nearly spherical vesicles ranging in diameter from approx. $0 . I$ to $2 \mu \mathrm{m}$ (Fig. $2 \mathrm{~A}$ ). Often many small vesicles were contained within larger ones. Occasionally, junctional structures were encountered. They usually appeared as sheets rather than vesicles. A high-resolution micrograph of such a structure is shown in Fig. $2 \mathrm{~B}$. At high magnification, the membranes clearly reveal the familiar trilaminar appearance as is shown in Fig. $2 \mathrm{C}$. 


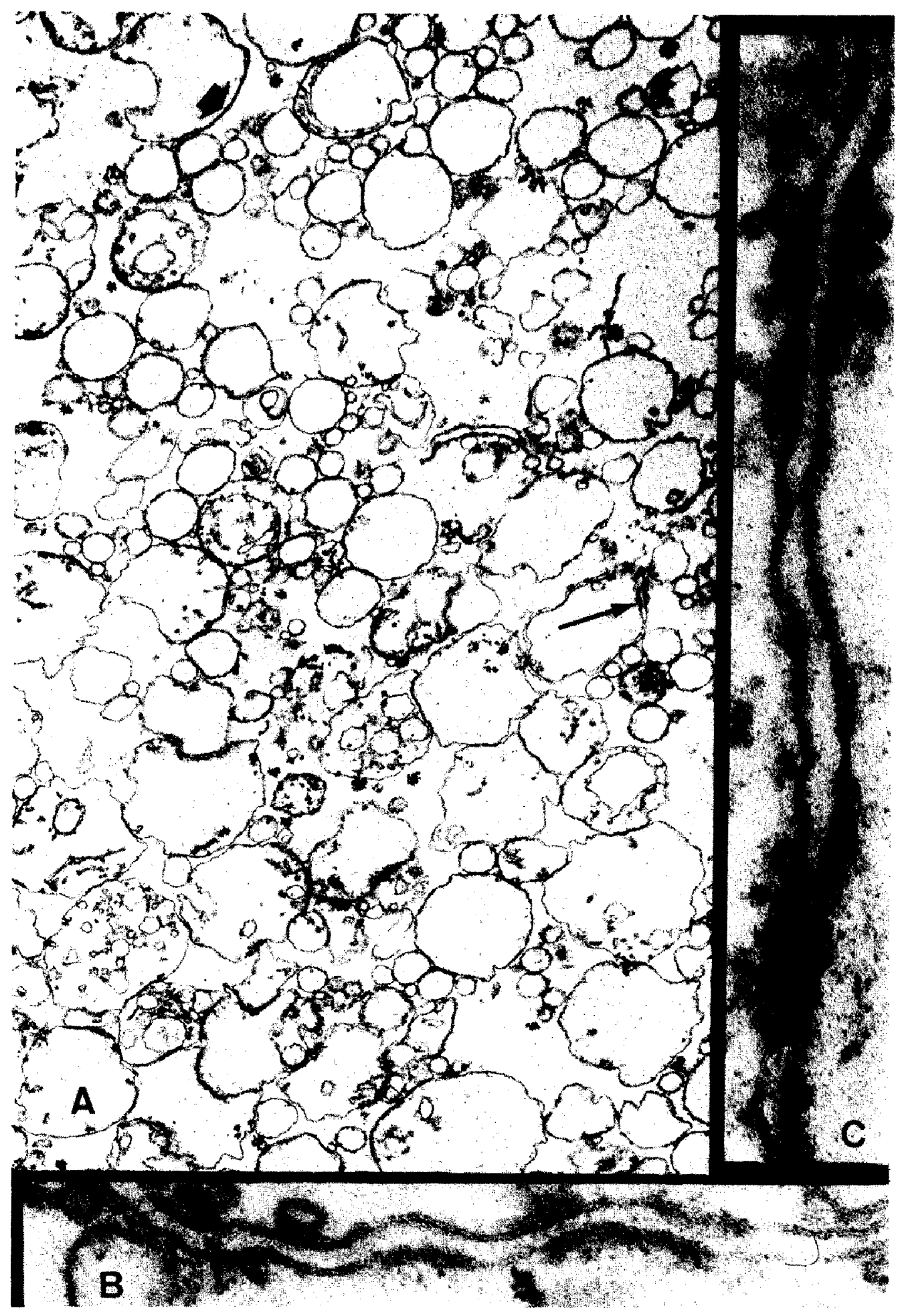

Fig. 2. Electron micrographs of thin sections of plasma membrane preparations. A. Low-magnification survey micrograph. The thick arrow points to an apparent double-membrane structure which, upon higher magnification, resolves into two triple-layered membranes in close proximity (see $F i g .2 \mathrm{~B}$ ). The thin arrow indicates an area containing junctional structures as shown in Fig. $2 \mathrm{C}$. Magnification, $19000 \times$. B. High resolution picture of an area as indicated by the thick arrow in Fig. 2A. Magnification, I $70000 \times$. C. High resolution picture of a junctional complex. Magnification, $170000 \times$ 


\section{Biosynthesis of phosphatidylglycerol in plasma membranes}

Phosphatidylglycerol was the only detectable product of $s n$-glycerol-3-phosphate esterification by plasma membranes in the presence of CDP-diglyceride. The product was identified as follows: Thin-layer chromatography of the total lipid extract in chloroform-methanol-water-25\% ammonia (70:30:3:2, by vol.) and in chloroform-methanol-acetic acid-water $(50: 25: 7: 3$, by vol.) gave a single radioactive spot which co-chromatographed with phosphatidylglycerol isolated and purified from Mycoplasma laidlawait. There was a single radioactive spot on the paper chromatogram of the water-soluble products produced by the action of phospholipase $\mathrm{D}$ on the radioactive lipid product. The spot had an $R_{F}$ of 0.69 . This value was identical to that obtained with glycerol, whereas glycerol-3-phosphate had an $R_{F}$ value of $0.2 \mathrm{I}$ in this solvent system. These results establish that the radioactive lipid product synthesized by plasma membranes is phosphatidylglycerol.

\section{Phosphatidylglycerol synthesis reaction characteristics}

The velocity of the reaction was measured by the rate of appearance of radioactive lipid product. Under the assay conditions, the rate of synthesis was directly proportional to the protein concentration and length of incubation. The reaction had a broad $\mathrm{pH}$ optimum with a maximum at 7.5 . The relationship between $s n$-glycerol3-phosphate concentration and phosphatidylglycerol synthesized is shown in Fig. 3 . The apparent $K_{m}$ was I.9.10-5 M. Fig. 4 relates the velocity of the reaction to CDPdiglyceride concentration. The apparent $K_{m}$ value for the reaction was $3 \cdot 4 \cdot 10^{-5} \mathrm{M}$.
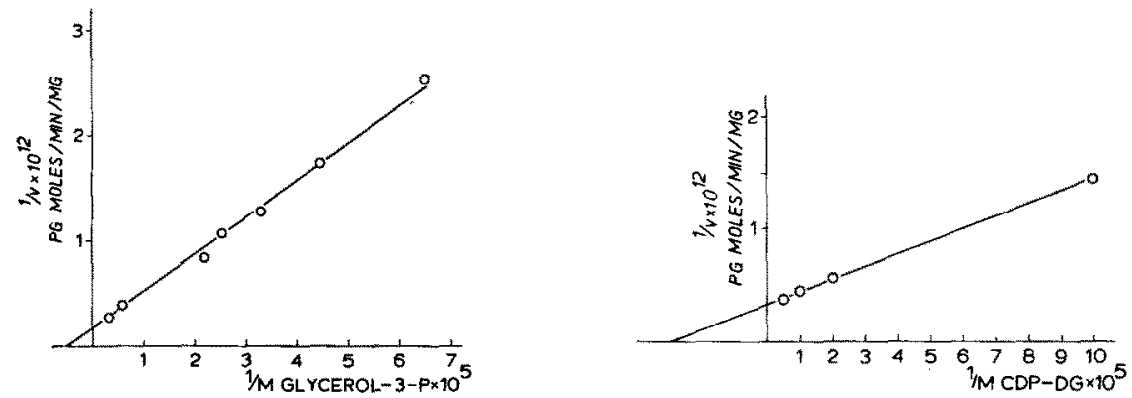

Fig. 3. Double-reciprocal plot of the formation of phosphatidylglycerol (PG) as a function of $s n$-glycerol-3-phosphate concentration. The incubation mixture contained $50 \mathrm{mM}$ Tris- $\mathrm{HCl}, \mathrm{pH} 7 \cdot 5$, $16 \mathrm{mM} \beta$-mercaptoethanol, $0.1 \mathrm{mM}$ CDP-diglyceride, $0.088 \mathrm{mg}$ plasma membrane protein and the varying concentrations of sn-glycerol-3-phosphate in a total volume of $0.5 \mathrm{ml}$. Incubations were carried out at $37^{\circ}$ for $60 \mathrm{~min}$.

Fig. 4. Double-reciprocal plot of the formation of phosphatidylglycerol (PG) as a function of CDP-diglyceride (CDP-DG) concentration. The incubation mixture contained $0.038 \mathrm{mM} s n$ glycerol-3 phosphate and varying concentrations of CDP diglyceride (CDP-DG) but was otherwise the same as given for Fig. 3 .

Deacylation of exogenous labeled phospholipids by plasma membrane phospholipase

The phospholipase A activity of plasma membrane was measured by the appearence of labeled products, either lysophospholipids or fatty acids. For all substrates, the reaction was measured under conditions of linear dependence on protein concentration and length of incubation. 


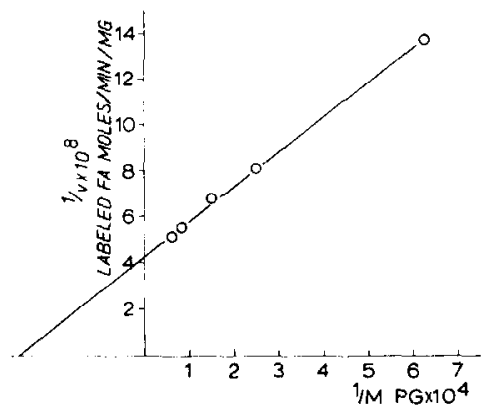

Fig. 5. Plasma membrane phospholipase A activity. Kinetics of labeled fatty acid (FA) release as a function of I-palmitoyl-[2-14C]oleoyl-3-sn-phosphatidyl-I'sn-glycerol (PG) concentration. The incubation volume of $0.25 \mathrm{ml}$ contained $0.050 \mathrm{mg}$ plasma membrane protein, 10 $\mathrm{mM} \mathrm{Ca}{ }^{2+}, 70 \mathrm{mM}$ Tris-maleate, $\mathrm{pH} 8.0$, and $\mathrm{PG}$. The reaction was stopped after $15 \mathrm{~min}$ at $37^{\circ}$.

When I-palmitoyl-2-[I-14C]oleoyl-3-sn-phosphatidyl-I'-sn-glycerol was incubated with plasma membranes, fatty acid was the main labeled product. The effect of substrate concentration on fatty acid release is shown in Fig. 5. An apparent $K_{m}$ value of $3.6 \cdot \mathrm{IO}^{-5} \mathrm{M}$ was obtained and $v_{\max }$ was $2.3 \mathrm{nmoles} / \mathrm{min}$ per $\mathrm{mg}$ protein. Using I-saturated-2- $\left[\mathrm{I}^{-14} \mathrm{C}\right]$ linoleoyl-phosphatidylethanolamine as a substrate, an apparent $K_{m}$ value of $5 \cdot 10^{-4} \mathrm{M}$ was obtained, whereas $v_{\max }$ was found to be 6.6 nmoles ${ }^{14} \mathrm{C}$ labeled fatty acid released per min per $\mathrm{mg}$ protein. In addition to indicating a phospholipase A activity in plasma membranes, the results suggest that the action may be directed to the 2-position of the phospholipid molecule mainly.

TABLE II

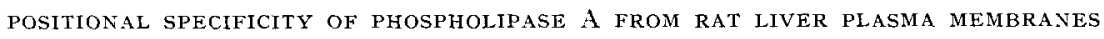

Incubations were carried out as described in MATERIALS AND METHODS. The monoacyl phosphoglyceride and fatty acids formed were assayed for radioactivity. The ratio of radioactivity in the fatty acids to that in monoacylphosphoglycerides is shown.

\begin{tabular}{|c|c|c|c|c|c|}
\hline \multirow[t]{3}{*}{ Substrate } & \multirow{3}{*}{$\begin{array}{l}\text { Isotopic distribution } \\
\text { in substrate } \\
(C-I / C-2)\end{array}$} & \multicolumn{4}{|c|}{$\begin{array}{l}\text { Released fatty acid radioactivity/released } \\
\text { monoacylphosphoglyceride radioactivity }\end{array}$} \\
\hline & & \multirow[t]{2}{*}{ Microsomes } & \multicolumn{3}{|c|}{ Plasma membranes } \\
\hline & & & $I^{*}$ & $2 * *$ & $3^{* * *}$ \\
\hline$\left[{ }^{3} \mathrm{H}\right]$ Phosphatidylglycerol & $74 / 26$ & $76 / 24$ & $27 / 73$ & -- & - \\
\hline$\left[{ }^{14} \mathrm{C}\right]$ Phosphatidylglycerol & $20 / 80$ & $23 / 77$ & $85 / 15$ & - & 一 \\
\hline$\left[{ }^{14} \mathrm{C}\right]$ Phosphatidylethanolamine & $3 / 97$ & $\mathrm{I} 3 / 87$ & $78 / 22$ & $70 / 30$ & $7^{6 / 24}$ \\
\hline
\end{tabular}

* Membranes prepared as described in this paper.

* Membranes provided by Prof. Emmelot.

*** Membranes (from beef liver) provided by Prof. Fleischer.

In order to confirm the latter point, a series of experiments was carried out with various phospholipids labeled at the $I$ - or 2-positions. As the results in Table II indicate, while microsomes are phospholipase $A_{1}$-specific ${ }^{21,22}$, phospholipase $A_{2}$ specificity predominates in plasma membranes. In agreement with findings on mitochondria and microsomes ${ }^{19,21}$, phosphatidylcholine was not significantly hydrolyzed. The results in Table II are consistent with the presence of only phospholipase $A_{2}$ activity in the experiments where phosphatidylglycerol was the substrate. However, with phosphatidylethanolamine as a substrate, the results suggest the presence of both phospholipase $A_{2}$ and $A_{1}$ activities, the former being predominant.

Biochim. Biophys. Acta, 239 (1971) 443-457 
In order to obtain an independent check on the phospholipase $\mathbf{A}_{\mathbf{2}}$ specificity and, indirectly, on the purity of our plasma membrane preparations, phospholipase assays were carried out with membranes generously donated by Prof. Dr. P. Emmelot (Department of Biochemistry, Netherlands Cancer Institute, Amsterdam) and Prof. Dr. S. Fleischer (Department of Molecular Biology, Vanderbilt University, Nashville). The results obtained were similar to those obtained using our own membranes and confirm that plasma membrane phospholipase $A$ activity is primarily specific for the 2-position.

A partial characterization of the enzyme was undertaken. The $\mathrm{pH}$ optimum for

TABLE III

\section{ENZYMATIC PROPERTIES OF PLASMA MEMBRANE PHOSPHOLIPASE A}

The standard enzymic assay contained o.o6o mg plasma membrane protein, $80 \mu \mathrm{M}$ I-palmitoyl[2-14C] oleoyl-3-sn-phosphatidyl-I'-sn-glycerol, Io $\mathrm{mM} \mathrm{Ca}^{2+}$, and $70 \mathrm{mM}$ Tris-maleate, $\mathrm{pH} 8.0$, in a total volume of $0.25 \mathrm{ml}$. The incubation was carried out at $37^{\circ}$ for $15 \mathrm{~min}$. When used, the following reagents were present in these concentrations or amounts: 1o $\mathrm{mM} \mathrm{Mg}^{2+}, 2 \mathrm{mM} N$-ethylmaleimide, 50 $\mathrm{mM}$ EDTA and o.I $\mathrm{mg}$ deoxycholate.

\begin{tabular}{|c|c|}
\hline Enzymic assay & $\begin{array}{l}\text { Fatty acid released } \\
\text { (nmoles/min per mg protein) }\end{array}$ \\
\hline Control & I. 75 \\
\hline $\mathrm{No} \mathrm{Ca}^{2+}$ & 0.73 \\
\hline No $\mathrm{Ca}^{2+}$, plus EDTA & 0.29 \\
\hline EDTA & 0.33 \\
\hline No $\mathrm{Ca}^{2+}$ plus $\mathrm{Mg}^{2+}$ & 0.60 \\
\hline$N$-Ethylmaleimide & I. 77 \\
\hline Io $\min$ at $70^{\circ}$ & 0.76 \\
\hline Deoxycholate & I. 73 \\
\hline
\end{tabular}

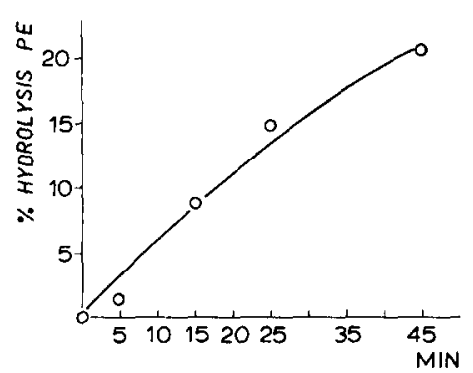

Fig. 6. Deacylation of endogenously labeled phosphatidylethanolamine (PE) by plasma membrane phospholipase. For details, see MATERIALs AND METHODS.

phospholipase hydrolysis was 8.o. Table III shows the effect of various modifications of the incubation medium on phospholipase activity. The enzyme had a requirement for calcium. The presence of $N$-ethylmaleimide or deoxycholate had no effect. In agreement with data on other phospholipase ${ }^{50}$, the enzyme was rather heat stable.

As Fig. 6 indicates, a significant amount of endogenous phosphatidylethanolamine hydrolysis can occur due to phospholipase $\mathrm{A}$ activity. The rate of reaction was linear with time over the range studied.

\section{Lysophospholipase activily in plasma membranes}

Previous work from this laboratory has shown that a lysophospholipase is pre- 
sent in rat liver and that this enzyme is localized predominantly in the $100000 \times \mathrm{g}$ supernatant fraction ${ }^{45}$. Table IV shows that no detectable amount of lysophospholipase was found in rat liver plasma membranes when compared to the activity of this enzyme in the $100000 \times g$ supernatant.

\section{TABLE IV}

HYDROLYSIS OF I- $\left[{ }^{14} \mathrm{C}\right]$ PALMITOYL- $n$-GLYCERO-3-PHOSPHORYLCHOLINE BY IOOOOO $\times g$ SUPERNATANT AND PT.ASMA MFMBRANFS FROM RAT TIVFR

20 nmoles of $\mathrm{I}$ - $\left[{ }^{14} \mathrm{C}\right]$ palmitoyl-sn-glycero-3-phosphorylcholine were incubated for $\mathrm{I}_{5} \mathrm{~min}$ with the indicated amount of proteins in a final volume of $1 \mathrm{ml}$. The amount of ${ }^{14} \mathrm{C}$-labeled fatty acjds released was measured as described in detail in a previous work from this laborator $y^{45}$.

\begin{tabular}{lll}
\hline $\begin{array}{l}\text { Amount of protein } \\
\text { added }(\mu \mathrm{g})\end{array}$ & $\begin{array}{l}\text { nmoles }\left[{ }^{4} \mathrm{C}\right] \text { palmitate released } \\
\text { Rat liver I00000 } \mathrm{g}\end{array}$ & $\begin{array}{l}\text { Rat liver plasma } \\
\text { membranes }\end{array}$ \\
\hline $5^{\circ}$ & $\begin{array}{l}\text { supernatant } \\
\text { IOO }\end{array}$ & $<0.05$ \\
200 & 5.1 & $<0.05$ \\
\hline
\end{tabular}

\section{DISCUSSION}

Several reports have appeared on the isolation of liver plasma membranes by zonal centrifugation ${ }^{3,51-53}$. However, in all cases the isolation procedure has involved A-type or size 5 zonal rotors. The plasma membrane fraction obtained by zonal centrifugation in the size $\mathrm{I}_{4}$ rotor shows very similar sedimentation behavior to that obtained in the larger size I5 rotor as described by ANDERSON ${ }^{3}$. The yield of our preparations is more comparable to that obtained by flotation methods ${ }^{54}$. This probably stems from the lower capacity of the rotor we employed.

The results of the marker enzyme tests clearly indicate that the only significant contamination in our plasma membrane preparation is endoplasmic reticulum (max. Io $\%$ ). This probably originates at the very beginning of the procedure when the cell is disrupted. Mitochondria and lysosomes are not present in significant amounts (less than $\mathrm{I} \%$ ) in the isolated plasma membranes as judged by marker enzyme tests and electron microscopy.

The absence of mitochondrial outer membranes was ascertained by the very low level of monoamine oxidase activity in the plasma membranes. Moreover, isolated outer membranes show a banding density of $28.5 \%$ sucrose $(\mathrm{w} / \mathrm{w})^{55}$, sufficiently far from that of plasma membranes $(4 \mathrm{I} .2 \%, \mathrm{w} / \mathrm{w})$ so as not to constitute a significant source of contamination.

The presence of phosphatidylglycerol in plasma membranes has recently been reported by RAY et al. ${ }^{8}$. In addition, cardiolipin, which is known to be synthesized from phosphatidylglycerol ${ }^{56,57}$, has also been detected in rat-liver plasma membranes ${ }^{9}$. KIYASU et al. ${ }^{26}$ have shown that the biosynthesis of phosphatidylglycerol takes place predominantly in the mitochondria, whereas the endoplasmic reticulum is the main locus for the synthesis of nitrogen-containing phospholipids. The present paper demonstrates that the synthesis of phosphatidylglycerol from CDP-diglyceride and glycero-3-phosphate occurs also in the plasma membrane of the rat liver cell. The specific activity of the enzyme catalyzing this synthesis in plasma membranes is about $30 \%$ of that in mitochondria. Therefore, the finding of phosphatidylglycerol 
biosynthesis cannot be accounted for by the mitochondrial contamination of the plasma membrane preparation which was shown to be less than $\mathrm{I} \%$. Finally, a series of incubations were carried out with and without penicillin $\mathrm{G}(200 \mathrm{units} / \mathrm{ml})$ and streptomycin $(200 \mu \mathrm{g} / \mathrm{ml})$. The antibiotics were found to have no effect on the rate of phosphatidylglycerol synthesis.

Choline phosphotransferase was not found in significant amounts in plasma membranes. This finding and earlier observations with mitochondria ${ }^{25,15}$ corroborate the idea that the de novo synthesis of lecithin is localized exclusively in the endoplasmic reticulum. On the other hand, both mitochondria ${ }^{13-15}$ and plasma membranes ${ }^{11}$ have been shown to possess the acyltransferases catalyzing the conversion of lysolecithin into lecithin. In a very recent paper, however, KAULEN et al. ${ }^{58}$ describe that the acyltransferases reported to be present in plasma membranes ${ }^{11}$ are due to microsomal contamination of the plasma membrane.

Phospholipases have been reported to occur in rat liver in mitochondria ${ }^{19,20}$, lysosomes ${ }^{22,23}$, and microsomes ${ }^{21,22}$. The mitochondrial phospholipase was found to be located predominantly in the outer membrane fraction ${ }^{58,60}$ and was shown to act preferentially at the 2-position of phospholipids in contrast to microsomal phospholipase $A$ which attacks primarily the I-position ${ }^{21,22}$. The very recent results of ToRQUEBIAU et al. ${ }^{24}$ demonstrating the presence of the phospholipase $A$ in rat liver plasma membranes with exogenous phospholipids as substrates did not include data on the positional specificity of this enzyme. The results in this paper show the presence of a phospholipase $A$ acting both on exogenous phosphatidylethanolamine and phosphatidylglycerol and on endogenous phosphatidylethanolamine. The enzymic activity was shown to be mainly phospholipase $A_{2}$ although the presence of activity towards the I-position of phosphatidylethanolamine cannot be explained completely by the microsomal contamination in our plasma membrane preparation. At the time that this paper was being submitted, an article by NEWKIRK AND WAITE ${ }^{B 1}$ appeared describing the presence of plasma membrane phospholipase activity which was predominantly $A_{1}$. Although it is difficult to calculate from the data given by these authors (the specific activities of the microsomal marker enzymes in the microsomal fraction are not given), this discrepancy may be due, in fact, to a higher degree of microsomal contamination in the preparation of NEWKIRK AND WAITE.

Our results indicate that the biosynthesis capacities of plasma membranes are not limited to the synthesis of phosphatidic acid which was observed by STEIN et al. ${ }^{11}$. Synthesis of phosphatidylglycerol can also take place at a significant rate in the plasma membrane. However, the plasma membrane apparently does not possess the enzyme(s) required for the de novo synthesis of nitrogen-containing phospholipids such as phosphatidylcholine. For the supply of these phospholipids, the plasma membrane may be dependent on the endoplasmic reticulum. In such processes an exchange protein as found in the cytoplasm by WIRTZ AND $Z_{\text {ILVERSMIT }}^{62}$ might play an important role.

\section{ACKNOWLEDGMENTS}

The present investigations have been carried out under the auspices of the Netherlands Foundation for Chemical Research (S.O.N.) and with financial aid from the Netherlands Organization for the Advancement of Pure Research (Z.W.O.). E.J.V. 
is a Postdoctoral Fellow of the American Cancer Society and K.Y.H. is a U.S. Public Health Service Postdoctoral Fellow in Medicine (Grant No.AM-I005).

The authors wish to thank Prof. Dr. P. Emmelor (Netherlands Cancer Institute, Department of Biochemistry, Amsterdam) and Prof. Dr. S. Fleischer (Vanderbilt University, Department of Molecular Biology, Nashville) for kindly providing prepparations of plasma membranes. The authors are much indebted to Miss A. H. Niemeyer for excellent technical assistance.

\section{REFERENCES}

I E. L. Benedetti and P. Emmelot, in A. J. Dalton and F. Haguenau, The Membranes, Academic Press, New York, I968, p. 33.

2 D. M. Neville, Jr., J. Biophys. Biochem. Cytol., 8 (1960) $4 \mathrm{I} 3$.

3 N. G. Anderson, A. I. Lansing, I. Lieberman, C. T. Rankin Jr. and H. Elrod, Wistar Inst. Monogr., 8 (I968) 23.

4 N. Takeuchi and H. Terayama, Exp. Cell Res., 40 (rg65) 32.

5 B. J. Dod and G. M. Gray, Biochim. Biophys. Acta, I 50 (I968) 397.

6 R. C. Pfleger, N. G. Anderson and F. Siyder, Biochemistry, 7 (1968) 2826.

7 W. L. Stahl and E. G. Trams, Biochim. Biophys. Acta, i63 (I968) 459.

8 T. K. Ray, V. P. Skipski, M. Barclay, E. Essner and F. M. Archibald, J. Biol. Chem., 244 (I969) 5528 .

9 R. WOOD, Arch. Biochem. Biophys., 14 I (1970) 174.

io R. Henning, H. D. Kaulen and W. Stoffel, Z. Physiol. Chem, 35 I (I97o) I I9I.

i I Y. Stein, C. Widnell and O. Stein, J. Cell Biol., 39 (1968) 185.

I 2 W. E. M. Lands, J. Biol. Chem., 235 (Ig60) 2233.

I3 G. L. Scherphof and L. L. M. Van Deenen, Biochim. Biophys, Acta, I I 3 (I966) 4 I7.

I4 W. Stoffel and H. G. Schiefer, $Z$. Physiol. Chem., 349 (Ig68) 1017.

I5 M. G. Sarzala, L. M. G. Van Golde, B. De Kruyff and L. L. M. Van Deenen, Biochim. Biophys. Acta, 202 (1970) 106.

16 W. E. M. Lands and I. MerkL, J. Biol. Chem., 238 (I963) 898.

i 7 L. L. M. Van Deenen, H. Van den Bosch, L. M. G. Van Golde, G. L. Scherphof and B. M. WAITE, Cellular Compartmentalization and Control of Fatty Acid Metabolism, Universitets forlaget, Oslo, I968, p. 89 .

i 8 H. Van den Bosch, L. M. G. Van Golde, A. J. Slotboom and L. L. M. Van Deenen, Biochim. Biophys. Acta, I52 (1968) 694.

I9 G. L. Scherphof and L. L. M. Van Deenen, Biochim. Biophys. Acta, 98 (1965) 204.

20 C. R. Rossi, L. Sartorelli, L. Tato, L. Baretta and N. Siliprandi, Biochim. Biophys. Acta, $98(\mathrm{I} 965) 207$.

2 I G. L. Scherphof, B. M. Waite and L. L. M. Van Deenen, Biochim. Biophys. Acta, i 25 (I966) 406 .

22 P. J. Björnstad, Biochim. Biophys. Acta, i 16 (I966) 500.

23 W. Stoffel and U. Trabert, Z. Physiol. Chem., 350 (1969) 836.

24 O. Torquebiau-Colard, M. Paysant, R. Wald and J. Polonovski, Bull. Soc. Chem. Biol., 52 (TO7O) IO6r.

25 G. F. Wilgram and E. P. Kennedy, J. Biol. Chem., 238 (I963) 26 I 5.

26 J. Y. Kiyasu, R. A. Pieringer, H. Paulus and E. P. Kennedy, J. Biol. Chem., 238 (r963) 2293.

27 H. D. Tisdale, in R. W. Estabrook and M. E. Pallman, Methods in Enzymology, Vol. Io, Academic Press, New York, 1967, p. 213.

28 H. Weissbach, T. E. Smith, J. W. Daly, B. Witkop and S. Udenfriend, J. Biol. Chem., 235 (I960) II60.

29 G. L. Sotrocasa, B. Kuylenstierna, L. Ernster and A. Bergstrand, J. Cell Biol., 32 (rgo $4 \mathrm{I} 5$.

3o M. G. Burdon, R. M. S. Smellie and J. N. Davidson, Biochim. Biophys, Acta, 9i (1964) 46.

3 I R. Wattiaux and C. De Duve, Biochem. J., 63 (1956) 606.

32 P. Emmelot and C. J. Bos, Biochim. Biophys. Acta, I 20 (1966) 369.

33 S. M. Duttera, W. L. Byrne and M. C. Ganoza, J. Biol. Chem., 243 (Ig68) 22 I6.

34 O. H. Lowry, N. J. Rosebrough, A. L. Farr and R. J. Randall, J.Biol. Chem., I93 (I95I) 265.

35 P. S. Chen, T. Y. Toribora and H. Warner, Anal. Chem., 28 (1956) I 756.

36 E. Kellenberger, A. Ryter and J. Séchaud, J. Biophys. Biochem. Cytol., 4 (1958) 671.

Biochim. Biophys. Acla, 239 (I97 I) 443-457 
37 P. F. Elbers and J. Pieters, J. Uttrastruct. Res., i i (1964) 25.

38 C. Bublitz and E. P. Kennedy, J. Biol. Chem., 2 I I (I954) 95 I.

39 R. N. McElhaney and M. E. Tourtelotte, J. Bact., IoI (I970) 72.

40 H. Goldfine, J. Lipid Res., 7 (I966) r46.

4 I E. G. Bligh and W. J. Dyer, Can. J. Biochem. Physiol., 37 (I959) 9 I I.

42 N. Shaw, P. F Smith and W. L. Koostra, Biochem. J., I07 (I968) 329.

43 V. P. SKIPSKi, R. F. Peterson and M. Barclay, Biochem. J., 90 (1964) 374.

44 C. Long, R. Odavic and E. J. Sargent, Biochem. J., 102 (1967) 216.

45 H. Van den Bosch, A. J. Aarsmax, A. J. Slotboom and L. L. M. Van Deenex, Biochim. Biophys. Acta, I64 (I968) 2 I 5.

46 W. Schneider and E. L. Huff, in G. H. Bourne, Cytology and Cell Physiology, Academic Press, New York, I964, p. I9.

47 D. F. Parsons, G. R. Williams, W. Thompson, D. Wilson and B. Chance, in E. QuagliaRello, S. PApa, E. C. Slater AND J. M. TAger, Mitochondrial Structure and Compartmentalization, Adriatrica Editrice, Bari, I967, p. 29.

48 G. L. Sottocasa, L. Ernster, B. Kuylenstierna and A. Bergstrand, in E. Quagliarelio, S. Papa, E. C. Slater and J. M. TAger, Mitochondrial Structure and Compartmentalization, Adriatrica Editrice, Bari, I967, 1. 74 .

$49 \mathrm{~J}$. W. Greenawalt and C. Schnaitman, $J$. Cell Biol., 46 (I970) I 73.

50 L. L. M. Van Deenen and G. H. De HaAs, Annu. Rev. Biochem., 35 (1966) I 57.

5 I A. A. El-Aaser, J. T. R. Fitzimons, R. H. Hinton, E. Reid, E. Klucis and P. Alexander, Biochim. Biophys. Acta, I 27 (I966) 553.

52 R. A. Weaver and W. Boyle, Biochim. Biophys. Acta, i73 (1969) 377.

53 W. H. Evans, Biochem. J., I66 (1970) 833.

51 P. Fmmetot, C. J. Bos, E. I. Renfoftet and Ph. Rümke, Riochim. Biophys. Acta, 9o (I964) I 26.

55 D. F. Parsons, G. R. Williams and B. Chance, Ann. N.Y. Acad. Sci., I37 (1966) 643.

56 N. Z. Stanacev, Y. Y. Chang and E. P. Kennedy, J. Biol. Chem., 242 (I967) 3018.

57 K. Y. Hostetler, II. Van den Bosch and L. L. M. Van Deenen, Biochim. Biophys. Acta, 239 (I97I) II3.

58 H. D. Kaulen, R. Henning and W. Stoffel, Z. Physiol. Chem., 35 I (1970) 1555.

59 M. WAITE, Biochemistry, 8 (I969) 2536.

6o ‥ M. Vignais and J. Nachbauer, Bull. Soc. Chem. Biol., 50 (ig68) I 473.

6 I J. D. Newkirk and M. WaIte, Biochim. Biophys. Acta, 225 (I97I) 224.

62 K. W. A. Wirtz ANd D. B. Zilversmit, J. Biol. Chem., 243 (I968) 3596.

Biochim. Biophys. Acta, 239 (197I) 443-457 